\title{
PENGEMBANGAN PEMBELAJARAN MENULIS CERITA PENDEK DENGAN MODEL MIND MAPPING PADA SISWA KELAS XI SMK NEGERI 11 SAMARINDA TAHUN PEMBELAJARAN 20182019
}

\author{
Hani Subakti \\ Universitas Widya Gama Mahakam Samarinda \\ Pos-el: hanisubakti@uwgm.ac.id
}

\begin{abstract}
ABSTRAK
Penelitian pengembangan pembelajaran menulis cerita pendek dengan model mind mapping pada siswa kelas XI SMK Negeri 11 Samarinda perlu dilakukan. Hal ini, disebabkan masih kurangnya pemahaman siswa terhadap penulisan cerita pendek. Metode penelitian yang digunakan yaitu penelitian dan pengembangan (research and development) dengan model Borg dan Gall. Berdasarkan analisis data diperoleh hasil penelitian pengembangan pembelajaran menulis cerita pendek dengan model mind mapping pada siswa kelas XI SMK Negeri 11 Samarinda, (1) dinyatakan memiliki kevalidan dari kedua validator yaitu penilaian validator ahli sastra mendapatkan nilai $94 \%$ dengan kriteria sangat baik dan penilaian validator pembelajaran Bahasa dan Sastra Indonesia mendapatkan nilai 96\% dengan kriteria sangat baik (2) dinyatakan memiliki kepraktisan berdasarkan penilaian praktisi (teman sejawat) dengan mendaptkan nilai 96\% dengan kriteria sangat baik (3) dinyatakan memiliki keefektifan dilihat dari uji kelompok kecil pada saat pretes dengan rata-rata $67,16 \%$ dan postes dengan rata-rata $87,16 \%$ dan standar deviasi 8,51, serta uji kelompok besar pada saat pretes dengan rata-rata $67,7 \%$ dan postes dengan rata-rata $89 \%$ dan standar deviasi 18,42 .
\end{abstract}

Kata Kunci: Pengembangan, Pembelajaran Menulis Cerita Pendek, Model Mind Mapping.

\section{ABSTRACT}

Research development of learning to write a short story with mind mapping model on students of XI SMK Negeri 11 Samarinda needs to be done. This is due to the lack of students' understanding of short story writing. The research method used is research and development (research and development) with Borg and Gall model. Based on data analysis, the research result of learning development of short story writing with mind mapping model on students of XI SMK Negeri 11 Samarinda, (1) stated has validation of validator validator score of $94 \%$ with excellent criteria and assessment validator of Indonesian Language and Literature learning scores $96 \%$ with very good criterion (2) stated having practicability based on practitioner's appraisal (peers) with mendaptkan value $96 \%$ with very good criterion (3) expressed to have effectiveness seen from small group test at the time of pretes with an average of $67.16 \%$ and postes with an average of $87.16 \%$ and a standard deviation of 8.51 , as well as a large group test at pretest with an average of $67.7 \%$ and postes with an average of $89 \%$ and a standard deviation 18.42 .

Keywords: Development, Short Story Writing Lesson, Mind Mapping Model. 


\section{PENDAHULUAN}

Peta pikiran atau mind mapping adalah model pembelajaran yang tepat untuk mengatasi kesulitan siswa di dalam pembelajaran menulis cerita pendek. Berangkat dari kesulitan siswa dalam memahami dan menerapkan unsur-unsur intrinsik dan unsur-unsur ekstrinsik dalam menulis cerita pendek yang dibuatnya maka dipilihlah model peta pikiran (mind mapping). Model yang dipopulerkan oleh Tony Buzan ini merupakan model yang efektif untuk meningkatkan kemampuan tulis menulis bagi siswa.

Melaksanakan

model

pembelajaran dengan peta konsep atau mind mapping pada pembelajaran materi menulis cerita pendek perlu tahapan yang sistematis. Pertama-tama siswa diminta menuliskan satu kata kunci dari tema yang dipilih dan dituliskan di tengah-tengah kertas. Tema tersebut kemudian dijabarkan ke dalam rantingranting berupa unsur-unsur intrinsik cerita pendek yang meliputi alur/plot, penokohan, perwatakan, latar/setting, sudut pandang/poin of view, dan pesan dari cerita yang telah dipilih. Pada dasarnya model ini memudahkan siswa dalam membuat perencanaan sebelum menulis cerita pendek.

Perencanaan tulisan sering dikenal dengan pembuatan kerangka karangan, maka dalam model peta konsep/mind mapping, pembuatan kerangka karangan tersebut berupa kata kunci yang telah dilengkapi dengan gambar berwarna-warni yang dipetakan. Selain lebih menarik, kelebihan dari peta pikiran/mind mapping ini adalah siswa dapat menambah kata kunci dalam kegiatan menulisnya mendapatkan ide baru lagi. Peta pikiran/mind mapping tersebut dapat terus berkembang sesuai dengan keinginan penulisnya. Dengan demikian, dalam model ini, siswa dibebaskan untuk menulis "apa pun" sesuai dengan keinginan serta kreativitas. Di samping itu, simbol serta gambar berwarna-warni yang digunakan berpotensi mengoptimalkan fungsi kerja otak kanan yang memacu kreativitas serta imajinasi sehingga diharapkan siswa tidak kehabisan ide dalam menulis cerita pendek.

Kompetensi dasar (KD) menulis cerita pendek terdapat di dalam kurikulum mata pelajaran Bahasa Indonesia, salah satunya di dalam standar kompetensi (SK) kelas XI semester I/ganjil tentang mengungkapkan pengalaman diri sendiri dan orang lain ke dalam cerita pendek. Implikasi dari kurikulum tersebut menuntut semua siswa SMA/SMK di Indonesia mampu menulis cerita pendek. Namun, pada kenyataannya, masih banyak siswa yang hingga kini masih merasa kesulitan. Alasan yang mereka ajukan pun beraneka ragam, seperti: merasa tidak berbakat menulis, tidak memiliki ide mau menulis apa, sulit memulai dalam menulis, ide menulis macet di tengah jalan, sulit membangun konflik di dalam menulis, tidak bisa mengakhiri tulisan, serta kesulitan dalam mengembangkan gagasan di dalam tulisan.

Kendala yang paling banyak dihadapi para siswa SMK Negeri 11 Samarinda dalam pembelajaran menulis cerita pendek salah satunya adalah kesulitan dalam memberikan sifat fiktif dalam menulis cerita pendek. Suatu karangan narasi yang tidak memiliki sifat fiktif bukanlah cerita pendek, melainkan laporan ataupun catatan harian. Kendala berikutnya banyak siswa yang kesulitan dalam menyajikan konflik sehingga tulisan yang dihasilkan menjadi datar saja. Hal ini, tentu membuat tulisan mereka menjadi kurang menarik. Padahal, daya tarik dari sebuah cerita pendek salah satunya terletak pada konfliknya. Berdasarkan kondisi tersebut, penulis mengadakan penelitian dengan judul "pengembangan pembelajaran menulis cerita pendek dengan menggunakan model mind 
mapping pada siswa kelas XI SMK Negeri 11 Samarinda”.

\section{METODE PENELITIAN}

Penelitian ini menggunakan metode penelitian deskriptif kualitatif. Penggunan metode ini bertujuan untuk meneliti suatu objek secara alamiah yang dideskripsikan secara akurat dan sistematis. Semua datanya diuraikan sesuai dengan kenyataan yang ditemukan di lapangan saat penelitian (Moleong, 2007: 209). Berdasarkan data dan sumber data yang dibutuhkan dalam penelitian maka penelitian ini tergolong dalam penelitian deskriptif karena peneliti terlibat langsung ke lapangan untuk mengumpulkan data yang dibutuhkan dalam penelitian.

Penelitian ini menggunakan metode penelitian dan pengembangan (Research and Development) yang telah diadaptasi. Metode penelitian dan pengembangan (research and development) adalah metode penelitian yang digunakan untuk menghasilkan produk tertentu dan menguji keefektifannya. Menurut Borg and Gall, yang dimaksud dengan model penelitian dan pengembangan adalah " $a$ process used develop and validate educational product".

Penelitian pengembangan sebagai usaha mengembangkan dan memvalidasi produk-produk yang digunakan dalam proses pembelajaran. Produk di sini tidak hanya suatu yang berupa benda seperti buku teks, film untuk pembelajaran dan software (perangkat lunak) komputer, tetapi juga metode seperti metode mengajar, dan program seperti program pendidikan dan lainnya. Penelitian dan pengembangan berfungsi untuk memvalidasi dan mengembangkan produk. Memvalidasi produk, berarti produk itu telah ada, dan peneliti hanya menguji keefektivitas atau validitas produk tersebut.

Mengembangkan produk dalam arti yang luas dapat berupa memperbarui produk yang telah ada (sehingga menjadi lebih praktis, efektif, dan efisien) atau menciptakan produk baru (yang sebelumnya belum pernah ada). Tahap pengembangan dalam penelitian ini peneliti berusaha mencapai penelitian dan pengembangan pada level 3. Produk yang telah ada dari pemerintah akan dikembangkan dengan menambahkan produk baru agar lebih praktis, kreatif, serta efisien untuk diterapkan pada siswa SMK, lalu menguji keefektifan produk tersebut

Sugiyono menyebutkan langkah penelitian dan pengembangan seperti ditunjukkan pada gambar sebagai berikut:

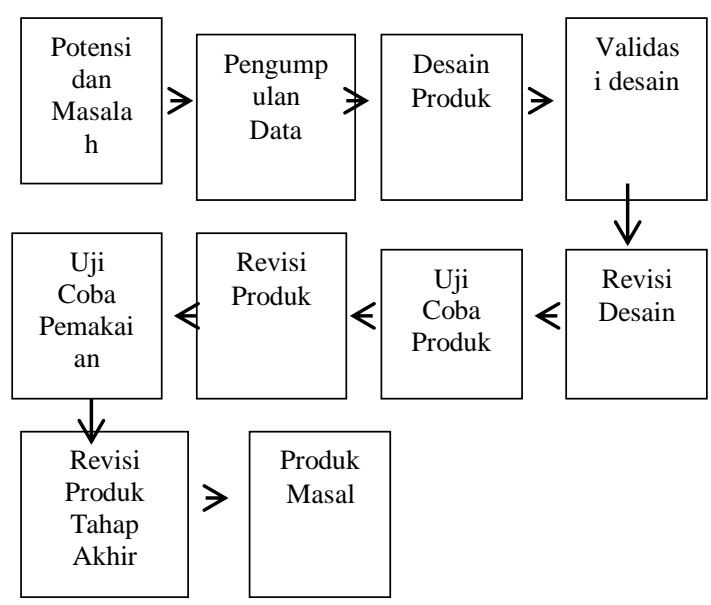

Langkah-langkah Penggunaan Metode R\&D Diadaptasi dari Sugiyono.

Subjek penelitian ini adalah siswa kelas XI SMK Negeri 11 Samarinda Tahun Pembelajaran 2018/2019 yang telah dipilih secara acak.

Instrumen yang digunakan dalam penelitian ini ada dua yaitu: (1) lembar observasi merupakan alat ukur keberhasilan yang digunakan oleh peneliti. Lembar observasi siswa bertujuan melihat aktivitas siswa dalam proses pembelajaran bahasa Indonesia pada kelas XI SMK. (2) lembar uji validasi yang digunakan untuk proses penilaian para ahli terhadap hasil pengembangan produk.

Penelitian ini dilaksanakan di SMK Negeri 11 Samarinda yang 
beralamat di Jalan Solo 3 RT 19 Blok B, Kelurahan Simpang Pasir, Kecamatan Palaran, Kota Samarinda. Waktu penelitian ini akan dilaksanakan pada bulan Februari s.d. Maret tahun 2019.

Prosedur penelitian ini dilaksanakan secara langsung dengan tahap-tahap yang telah dirancang sebelumnya. Tahapan-tahapan tersebut terdiri dari observasi lapangan, pemberian tugas-tugas, penerapan atau pengaplikasian produk hasil pengembangan, dan uji validasi atas produk.

Dalam penelitian ini pengumpulan data diperoleh melalui observasi, penugasan, uji para ahli, dan dokumentasi. Observasi dalam penelitian ini menggunakan lembar observasi siswa dengan cara mengamati aktivitas siswa. Penugasan digunakan untuk melihat hasil kerja siswa. Uji para ahli digunakan untuk melihat seberapa baik produk yang dihasilkan. Dokumentasi digunakan sebagai alat bukti penelitian pengembangan produk penelitian.

Data kevalidan terhadap produk pengembangan diperoleh dari penilaian validator ahli sastra dan validator ahli pengembangan pembelajaran bahasa dan sastra Indonesia, yang telah ditunjuk sebelumnya, sementara hasil tersebut dianalisis berdasarkan kriteria skala Likert.

Indikator yang dijadikan tolak ukur dalam menyatakan penelitian pengembangan ini berhasil dan tepat guna adalah jika terjadi peningkatan hasil belajar siswa setelah menggunakan produk hasil penelitian dan respons yang baik dari validator terhadap proses pengembangan pembelajaran, kepraktisan, dan keefektivitasan pembelajaran menulis cerita pendek dengan model mind mapping pada siswa kelas XI SMK Negeri 11 Samarinda.

\section{HASIL DAN PEMBAHASAN Hasil Penelitian}

Hasil penelitian pengembangan pembelajaran menulis cerita pendek dengan model mind mapping pada siswa kelas XI SMK Negeri 11 Samarinda yaitu menghasilkan produk dan meningkatan hasil belajar siswa. Peningkatan hasil belajar pada materi menulis cerita pendek akan menjadi tolok ukur keberhasilan dari pengembangan produk dengan model mind mapping. Jadi produk pengembangan dan peningkatan hasil belajar ditujukan untuk memperkuat hasil akhir produk penelitian ini secara menyeluruh. Selain itu, penelitian ini juga mengukur kepratisan dan keefektifan yang dinilai dari praktisi/teman sejawat dan hasil kerja siswa yang dilakukan oleh peneliti terhadap subjek penelitian.

\section{Data Hasil Validasi Produk untuk Menilai Kevalidan Produk}

Validasi terhadap proses pengembangan pembelajaran menulis cerita pendek dengan model mind mapping pada siswa kelas XI SMK Negeri 11 Samarinda dilakukan oleh dua validator. Validator pertama adalah validator ahli sastra dan validator kedua adalah ahli pembelajaran Bahasa dan Sastra Indonesia. Validator pertama yaitu seorang dosen sastra Indonesia yang memahami benar dan mendalam aspek-aspek kesusastraan dan berkarier sebagai dosen di Fakultas Ilmu Budaya, Universitas Mulawarman bernama Syamsul Rijal, S.S., M.Hum. Sementara itu validator kedua yaitu seorang guru senior yang juga menjadi instrukstur nasional mengenai pembelajaran Bahasa dan Sastra Indonesia dan berkarier sebagai guru di SMA Negeri 3 Samarinda bernama Iwan Noviar, M.Pd.

Hasil keseluruhan penilaian akhir yang dilakukan oleh validator ahli sastra mendapatkan niali 94. Maka produk masuk dalam kriteria persentase 90$100 \%$ yang apabila dilihat dari tabel uji coba kelayakan produk, skor ini 
termasuk dalam kriteria atau kualifikasi sangat baik dan produk yang dihasilkan siap dimanfaatkan untuk kegiatan pembelajaran. Hasil keseluruhan penilaian akhir yang dilakukan oleh validator ahli pembelajaran Bahasa dan Sastra Indonesia mendapatkan niali 96. Maka produk masuk dalam kriteria persentase $90-100 \%$ yang apabila dilihat dari tabel uji coba kelayakan produk, skor ini termasuk dalam kriteria atau kualifikasi sangat baik dan produk yang dihasilkan siap dimanfaatkan untuk kegiatan pembelajaran.

\section{Data Hasil Validasi Produk untuk Menilai Kepraktisan Produk}

Validasi terhadap kepraktisan produk pengembangan pembelajaran menulis cerita pendek dengan model mind mapping pada siswa kelas XI SMK Negeri 11 Samarinda dilakukan oleh seorang Praktisi (teman sejawat). Hal ini, dimaksudkan untuk mengukur kepraktisan dalam pembelajaran di kelas yang telah dilaksanakan. Praktisi (teman sejawat) yang menjadi penilai produk bernama Heri Sucipto, M.Pd yang merupakan guru di SMK Negeri 11 Samarinda dan memiliki banyak prestasi baik di tingkat kota, provinsi, hingga nasional. Hasil keseluruhan penilaian akhir yang dilakukan oleh praktisi (teman sejawat) mendapatkan niali 96. Maka produk masuk dalam kriteria persentase $90-100 \%$ yang apabila dilihat dari tabel uji coba kelayakan produk, skor ini termasuk dalam kriteria atau kualifikasi sangat baik dan produk yang dihasilkan siap dimanfaatkan untuk kegiatan pembelajaran.

\section{Hasil Analisis Uji Coba Produk Kelompok Kecil untuk Menilai Keefektifan Produk}

Berdasarkan hasil analisis data yang diuraikan, terlihat nilai menulis cerita pendek dengan model mind mapping dalam penulisan cerita pendek kelompok kecil adalah sebesar 8,51.
Nilai thitung dapat dibandingkan dengan nilai $t_{\text {tabel }}$ yaitu tabel nilai persentil distribusi uji t dengan $\mathrm{db}=\mathrm{N}-1=12-1$ $=11$. Jadi, db $12-1=11$ dan $\mathrm{t}_{0} 0,975=$ 2,20 . Sementara $t_{\text {hitung }}=8,51$ dan $t_{\text {tabel }}=$ 2,20 yang berarti $\mathrm{H}_{0}$ ditolak. $\mathrm{H}_{0}$ ditolak apabila $t_{\text {hitung }}>t_{\text {tabel }}$ karena terjadi perubahan yang signifikan pada nilai siswa ketika menulis cerita pendek sebelum dan sesudah menggunakan model mind mapping.

Data hasil evaluasi kelompok kecil menunjukan rata-rata hasil belajar pretes sebesar 67,16 sedangkan rata-rata postest sebesar 87,16. Hal ini menunjukan bahwa penggunaan model mind mapping dapat meningkatkan kemampuan siswa dalam menulis cerita pendek. Hal ini dibuktikan dengan nilai postest siswa yang berada di atas kriteria ketuntasan minimal (KKM) yang telah ditetapkan, yaitu berada di atas nilai 75 .

\section{Hasil Analisis Uji Coba Produk Kelompok Besar untuk Menilai Keefektifan Produk}

Berdasarkan hasil analisis data yang diuraikan, terlihat bahwa nilai menulis cerita pendek dengan model mind mapping dalam penulisan cerita pendek pada uji kelompok besar atau uji lapangan adalah sebesar 18,42 Nilai $t_{\text {hitung dapat dibandingkan dengan nilai }}$ $t_{\text {tabel }}$ dengan $\mathrm{db}=\mathrm{N}-1=28-1=27$. Jadi, $\mathrm{db}$ $28-1=27$ dan $\mathrm{t}_{0} 0,975=2,001$. Apabila $\mathrm{t}_{\text {hitung }}=18,39$ dan $\mathrm{t}_{\text {tabel }}=2,001$ maka $\mathrm{H}_{0}$ ditolak, sebab $\mathrm{H}_{0}$ ditolak jika $\mathrm{t}_{\text {hitung }}>\mathrm{t}_{\text {tabel. }}$.

Data hasil evaluasi kelompok besar menunjukan rata-rata hasil belajar pretes sebesar 67,7 sedangkan rata-rata postes sebesar 89. Hal ini menunjukan bahwa penggunaan model mind mapping dapat meningkatkan kemampuan siswa dalam menulis cerita pendek di sekolah. Hal ini dibuktikan dengan nilai postes siswa yang berada di atas kriteria ketuntasan minimal (KKM) yang telah ditetapkan, yaitu berada di atas nilai 75 . 


\section{SIMPULAN}

Simpulan dalam penelitian pengembangan menulis cerita pendek dengan menggunakan model mind mapping yang diawali dengan melakukan kajian kurikulum dan pengidentifikasian masalah, selanjutnya adalah penentuan atau perumusan konsep-konsep materi yang sesuai dengan model pembelajaran yang dikembangkan. Pengembangan menulis cerita pendek dengan menggunakan model mind mapping ini dikembangkan dengan memperhatikan isi, stuktur, kosakata, kalimat, dan mekanik. Teks dan gambar yang ada dibuat semenarik mungkin agar pembaca tidak merasa bosan dalam membaca bahan ajar ini.

Pengembangan menulis cerita pendek dengan menggunakan model mind mapping memiliki kualitas yang sangat baik ditunjukan dengan penilaian validator ahli sastra mendapatkan nilai 94\% atau sangat baik, penialaian validator ahli pembelajaran Bahasa dan Sastra Indonesia mendapatkan nilai $96 \%$ atau sangat baik, dan penilaian praktisi (teman sejawat) mendapatkan nilai $96 \%$ atau sangat baik.

Pengembangan menulis cerita pendek dengan menggunkan model mind mapping efektif dalam meningkatkan hasil belajar siswa yang dibuktikan dengan peningkatan rata-rata hasil belajar siswa pada kelompok kecil dari nilai sebesar $67,16 \%$ mengalami peningkatan menjadi $87,16 \%$ dengan standar deviasi sebesar 8,51 dan uji kelompok besar dari nilai sebesar $67,7 \%$ menjadi $89 \%$ dengan standar deviasi $18,42 \%$. Hal ini membuktikan bahwa persebaran nilai rata-rata hasil belajar siswa tidak terlalu jauh dari perolehan nilai rata-rata kelas.

Berdasarkan hasil penelitian yang telah dilakukan, maka peneliti merekomendasikan beberapa hal:

Sebagai peneliti, penggunaan model pembelajaran mind mapping ini bisa menjadi salah satu model yang menjadi masukan untuk bisa dikembangkan pendidik dalam upaya meningkatkan keterampilan belajar bagi siswa.

Bagi guru agar dalam pembelajaran guru menaruh kepercayaan pada setiap siswa bahwa setiap perilaku akan membawa siswa lebih baik dan mandiri dalam mengerjakan sesuatu baik untuk diri sendiri maupun untuk oraang di sekitarnya.

Bagi siswa agar lebih semangat dan percaya diri dalam mengikuti pembelajaran sehingga akan memiliki banyak keterampilan terutama dalam berkarya.

\section{DAFTAR PUSTAKA}

Al-Tabany, Trianto Ibnu Badar (ed). (2015). Mendesain Model Pembelajaran Inovatof, Progresif dan Kontekstual: Konsep, Landasan, dan Implementasinya pada Kurikulum 2013 (Kurikulum Tematik Integratif/KTI). Jakarta: Prenadamedia Group.

Arikunto, Suharsimi. (2013). Prosedur Penelitian. Jakarta: Rineka Cipta.

Ghazali, Syukur. (2013). Pembelajaran Keterampilan Berbahasa dengan Pendekatan KomunikatifInteraktif: Bandung Refika Aditama.

Kementerian Pendidikan dan Kebudayaan. (2013). Bahasa Indonesia Wahana Pengetahuan. Jakarta: Kementerian Pendidikan dan Kebudayaan.

Kementerian Pendidikan dan Kebudayaan, Direktorat Pendidikan Dasar dan Menengah, Direktorat Pembinaan Sekolah Menengah Atas. (2016). Panduan Penilaian oleh Pendidik untuk Sekolah Menengah Atas. Jakarta: Kementerian Pendidikan dan Kebudayaan.

Kosasih, E. (2012). Dasar- Dasar Keterampilan Menulis. Bandung: 
Yrama Widya.

Mahsun. (2014). Teks dalam

Pembelajaran Bahasa Indonesia.

Jakarta: Rajawali Pers.

Permendikbud. (2016). Nomor 21,

Tentang Standar Isi Pendidikan

Dasar dan Menengah Bahasa

Indonesia SMA. Jakarta:

Kementerian Pendidikan dan

Kebudayaan.

Priyatni, Endah Tri. (2014). Desain Pembelajaran Bahasa Indonesia dalam Kurikulum 2013. Jakarta: Bumi Aksara.

Sani, Ridwan Abdullah. (2015). Inovasi Pembelajaran. Jakarta: Bumi Aksara.

Sugiyono. (2015). Metode Penelitian\& Pengembangan: Research and Development. Bandung: Alfabeta.

Suprijono, Agus. (2010). Cooperative Learning. Yogyakarta: Pustaka Pelajar.

Sutama, I Made. (2016). Pembelajaran Menulis.Yogyakarta: Pustaka Pelajar. 